1972

\title{
Biodeposition as a Factor in Sedimentation of Fine Suspended Solids in Estuaries
}

Dexter S. Haven

Virginia Institute of Marine Science

Reinaldo Morales-Alamo

Virginia Institute of Marine Science

Follow this and additional works at: https://scholarworks.wm.edu/vimsbooks

Part of the Marine Biology Commons

\section{Recommended Citation}

Haven, Dexter S. and Morales-Alamo, Reinaldo, "Biodeposition as a Factor in Sedimentation of Fine Suspended Solids in Estuaries" (1972). VIMS Books and Book Chapters. 16.

https://scholarworks.wm.edu/vimsbooks/16 


\title{
Biodeposition as a Factor in Sedimentation of Fine Suspended Solids in Estuaries
}

\author{
DEXTER S. HAVEN \\ and \\ REINALDO MORALES-ALAMO \\ Virginia Institute of Marine Science \\ Gloucester Point, Virginia 23062
}

\begin{abstract}
Filter feeders, such as mollusks, tunicates, and barnacles, ingest particles as small as 1 micron during their feeding process and void them in fecal pellets which range from 500 to 3,000 microns in length; these pellets settle at a much faster rate than their component particles. Feces and pseudofeces that settle to the bottom are termed biodeposits. Oyster biodeposits contain 77 to 91 percent inorganic matter, 4 to 12 percent organic carbon, and about 1.0 gram per kilogram of phosphorus. Fecal pellets are alternately deposited and resuspended by tidal currents. They settle and accumulate in areas of estuaries where the fine particles themselves would not. A portion of the biodeposits settling on sediment surfaces is mixed into subsurface deposits and may alter the textural and chemical properties of the original sediments.
\end{abstract}

\section{CONTENTS}

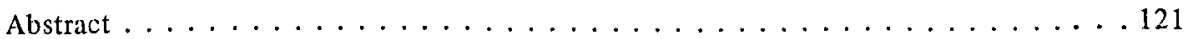

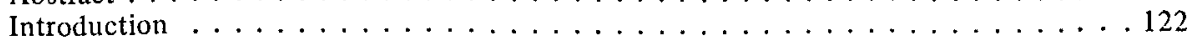

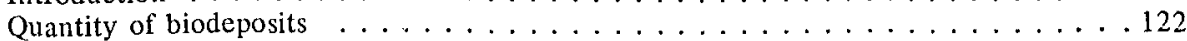

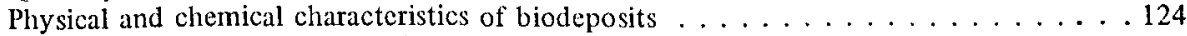

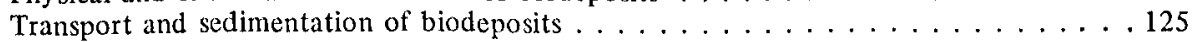

Mixing of biodeposits into bottom sediments . . . . . . . . . . . . . . . . . . . . . . . .

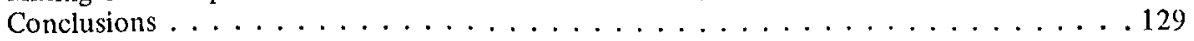

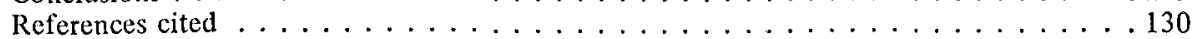




\section{Figure}

1. Theoretical biodeposition cycle in an estuary . . . . . . . . . . . . 123

2. Relative production of biodeposits by several filter-feeding organisms in the laboratory . . . . . . . . . . . . . . . . . . . . . . 124

3. Relation between mean weight of whole oysters and weekly rates of biodeposition -125

4. Relation between various components of the suspended sediment load and current velocity at a depth of $1 \mathrm{~m}$ above the bottom at White Shoal, James River, Virginia, 19-20 March 1965. . . . . . . . . . . . . . . . . . . . . 127

5. Settling velocity of fecal pellets from six species of invertebrate filter-feeders . . . . 128

6. Size distribution of component particles of fecal pellets of four species of filterfeeders and of oyster feces and pseudofeces . . . . . . . . . . . . . . 129

Table

1. Characteristics of fecal pellets collected in the laboratory and used for sinking

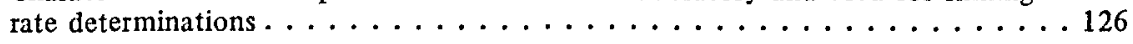

\section{INTRODUCTION}

Suspension-feeding marine invertebrates obtain food by filtration of suspended particulate matter from the water through gills or other retention structures. Many of these invertebrates, such as oysters, barnacles, tunicates, and copepods, ingest large quantities of small particles in the 1- to 5-micron range (Damas, 1935; Verwey, 1952; J $\phi$ rgensen, 1966; Haven and Morales-Alamo, 1970). In many molluscan species, some material is rejected before ingestion and ejected from the shell cavity in a loosely compacted mass termed pseudofeces. Ingested particles, after passage through the digestive tract, are voided into the water as compacted fecal pellets which range in length from 50 to 3,000 microns (Moore, 1931; Arakawa, 1963). Consequently, the pellets settle to the bottom at a faster rate than that of the particles originally in suspension; subsequently, they may be resuspended or mixed into bottom deposits (Fig. 1). Fecal pellets and pseudofeces are termed biodeposits; the entire process, including their settling to the bottom, is termed biodeposition (Haven and Morales-Alamo, 1966a).

The process of biodeposition may be at least as important as the abiotic process in initiating deposition of fine suspended solids. Moore $(1931,1936)$ stated that in the Clyde Sea during spring, fecal pellets from Calanus and euphausids are deposited at rates approaching 33.4 milligrams per square centimeter per week. In Japanese waters a single raft of oysters occupying 60 square meters may deposit from 0.6 to 1.0 ton of fecal material (dry weight) in a year (Ito and Imai, 1955). Verwey (1952) calculated that mussels in the Waddensea deposit between 25,000 and 175,000 metric tons of detritus annually. Lund (1957) studied biodeposition in the laboratory and suggested that one acre of oysters might deposit 7.6 metric tons of detritus annually.

Aspects of biodeposition studies conducted at the Virginia Institute of Marine Science, Gloucester Point, Virginia, are summarized below.

\section{QUANTITY OF BIODEPOSITS}

Small oysters (Crassostrea virginica) 5 to 8 centimeters long were held in circular troughs designed to collect all biodeposits and supplied with water 


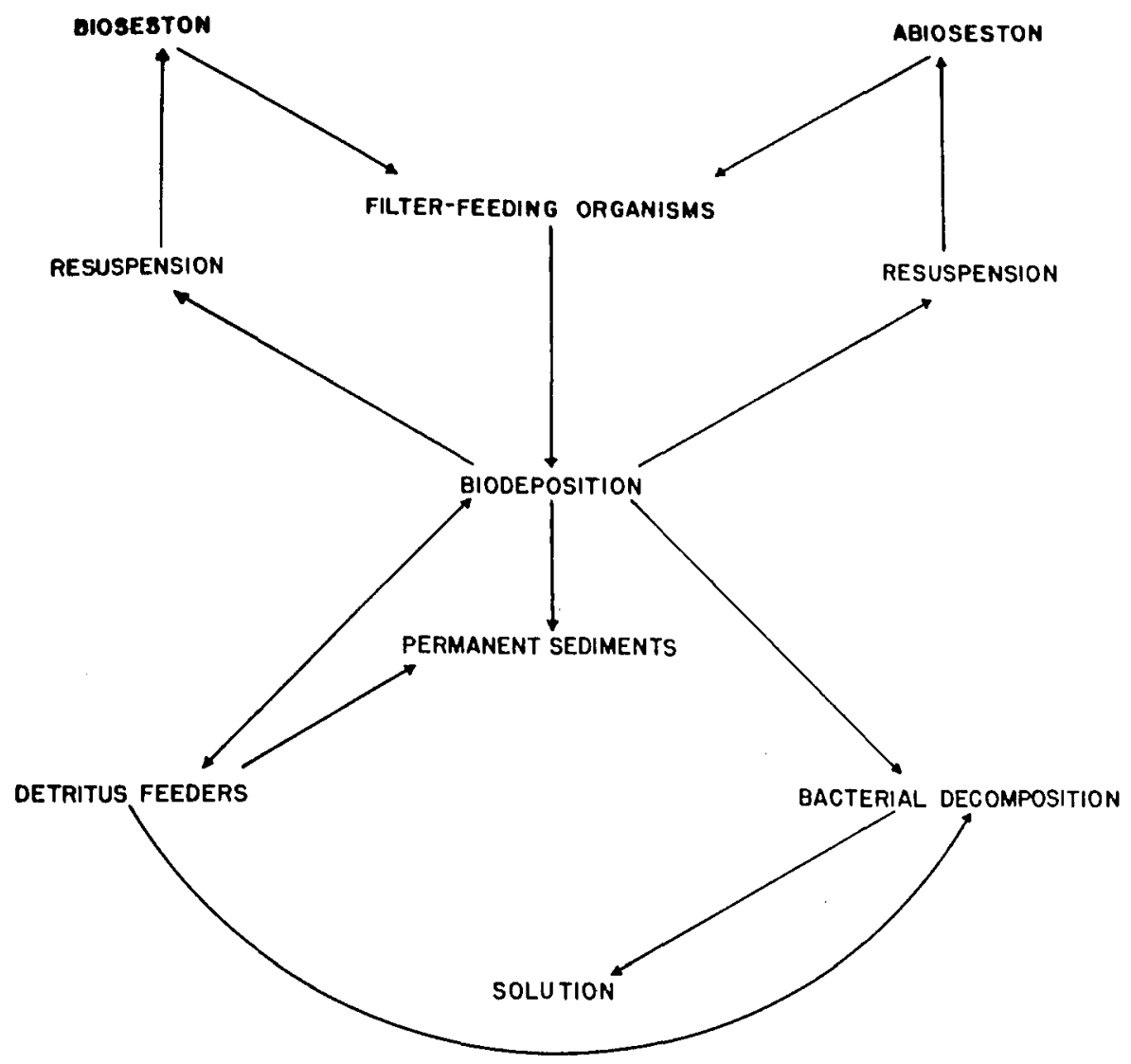

Figure 1. Theoretical biodeposition cycle in an estuary (from Haven and Morales-Alamo, 1966a).

pumped from the York River, Virginia (Haven and Morales-Alamo, 1965). During a 6-month period from May to October 1962, each oyster deposited an average of 1.62 grams per week solids with a maximum of 3.92 grams per week (dry weight). Comparison with control troughs, where empty shells replaced living oysters, showed the living oysters deposited solids seven times faster than they would settle by gravity.

The oyster is only one of many filter-feeders commonly found in estuaries. In many localities it is vastly outnumbered by other species. Biodeposition rates of other animals, including tunicates (Molgula manhattensis), soft clams (Mya arenaria), ribbed mussels (Modiolus demissus), and barnacles (Balanus eburneus), were studied in circular troughs. These rates were compared to that of the oyster. Differences in sizes of animals made direct comparisons difficult. Consequently, dry weight of animal tissue was determined for all animals after the study was completed and production of biodeposits was compared in terms of the ratio of the total weight of biodeposits produced to the total dry weight of the animals (Fig. 2). Tunicates removed more material than other species tested, while barnacles produced the least. 


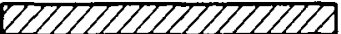

EZT]

JUN. 19- JUL. 14, 1963

C. VIRGINICA

QIZZZZZZZZZZZZTZZ

M.ARENARIA

QZ7]

M.MANHATTENSIS

B. EBURNEUS

\section{एपIII}

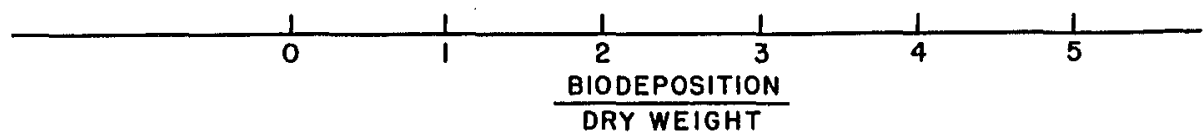

Figure 2. Relative production of biodeposits by several filter-feeding organisms in the laboratory expressed as the ratio of the total weight of biodeposits produced to the total dry weight of the animals.

Many factors influence biodeposition rates of filter-feeders. One of the most obvious is size of the animal. In a series of studies, oysters were selected to fall into four weight groups and held in circular troughs. Biodeposits were collected daily and their dry weight was compared to mean total weight and dry weight of the whole animal tissues. The largest oysters deposited relatively less material from suspension than did the smaller ones on the basis of total weight and dry tissue weights (Fig. 3).

Water temperature also influences biodeposition rates. Oysters were held in circular troughs throughout one winter, and quantities of biodeposits were collected weekly during the colder months. When water temperatures fell to about $7^{\circ} \mathrm{C}$, there was an 85 percent decrease in weights of biodeposits produced. During January and February when temperatures ranged below $2.8^{\circ} \mathrm{C}$, measurable quantities of biodeposits were not produced. Many species of filter-feeders exhibit a similar reduction in activity during the colder months. Consequently, production of biodeposits in an estuary is reduced during the winter.

\section{PHYSICAL AND CHEMICAL CHARACTERISTICS OF BIODEPOSITS}

Microscopic examination of biodeposits from filter-feeders showed a wide range in composition and physical appearance. Oyster biodeposits contained nearly every algal cell noted in plankton in the York River. Many of the cells appeared to be living although no effort was made to establish their viability definitely. When fecal strings were broken apart by shaking, it was observed that 
the cellular components were held together by a matrix of fine particles which included sand, silt, clay, diatom fragments, and sponge spicules. Pellets from other filter-feeders differed in their composition. For example, barnacle pellets contained mostly finely compacted silts and clays with only a few algae.

Oyster biodeposits have definite physical and chemical characteristics. Fixed residue after ignition showed an inorganic content ranging from 77 to 91 percent. X-ray diffraction analysis indicated that clay minerals made up from 70 to 90 percent of each sample; the major constituents were illite, chlorite, and mixed layer clay, with quartz, feldspar, and montmorillonite the minor minerals. Total organic carbon varied seasonally from 8.3 to 4.5 percent in spring and from 4.6 to 4.0 percent in fall. Total phosphorus, in determinations made on biodeposits collected during September and October 1962, varied from 1.7 to 0.3 gram per kilogram with a mean of about 1.0 gram per kilogram.

\section{TRANSPORT AND SEDIMENTATION OF BIODEPOSITS}

Biodeposits from marine invertebrates form a recognizable and measurable component of the total suspended load in the James River, Virginia, a typical Class B estuary (Haven and Morales-Alamo, 1968). During March 1965, a boat was anchored in 9 meters of water in the James River where bottom salinity varied from 10.6 to $14.0 \%$. Water samples for total solids determinations were pumped from 1 meter below the surface and 1 meter above the bottom. Current velocity measurements were taken from the same depths and at the same time intervals. Quantity of fecal pellets in suspension was determined by flowing water from various depths through soil analysis sieves (minimum mesh size 44 microns). All material collected by the sieve was preserved, and the numbers of pellets or

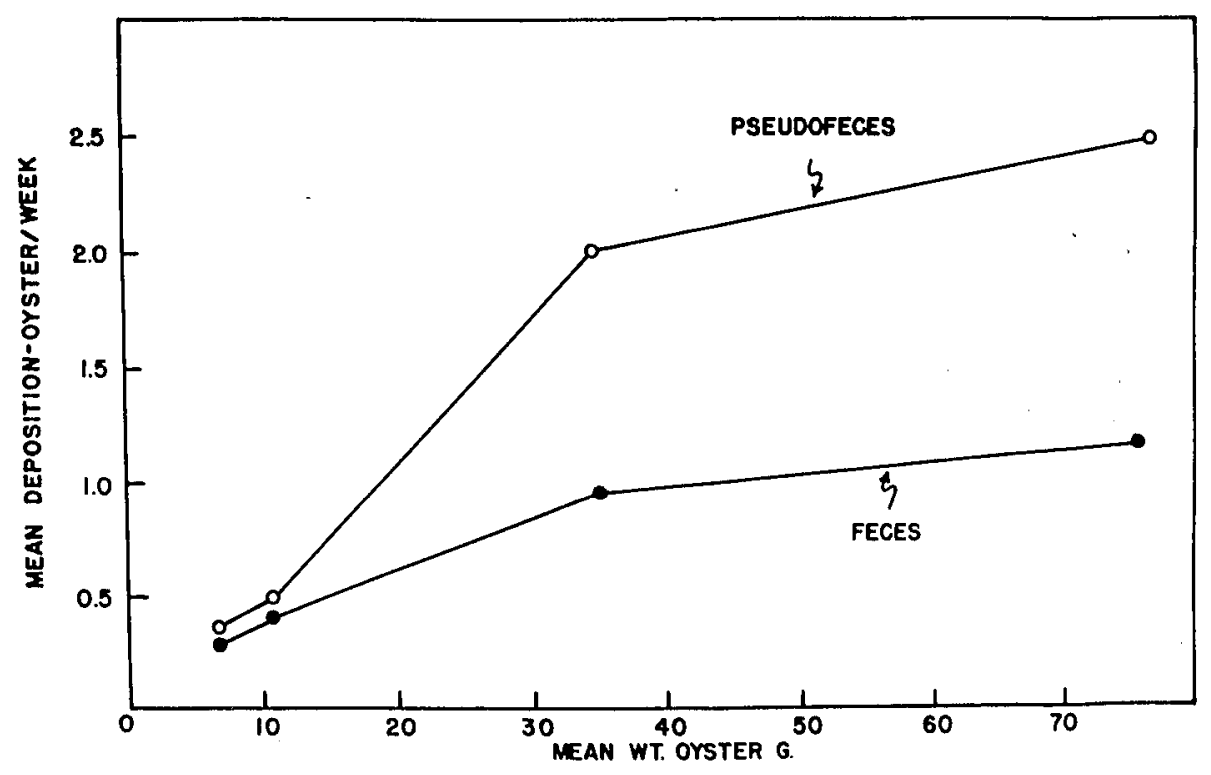

Figure 3. Relation between mean weight of whole oysters and weekly rates of biodeposition (from Haven and Morales-Alamo, 1966a). 
fragments were counted in representative samples. Pellet numbers were later converted to dry weights and compared to total dry weights of all sediments collected by the sieve. Fecal pellets or recognizable fragments formed an average of 0.42 percent by weight of total suspended solids at 1 meter above the bottom. Pellets retained by the 44 microns sieve comprised 26.6 percent of the material retained by the screen. Quantity of total solids and pellets in suspension varied with time, with maximum quantity occurring at peak current velocities and minimum values occurring at slack water (Fig. 4). This fluctuation implied alternate suspension and deposition of biodeposits.

Settling rates of fecal pellets collected during the preceding study and of those obtained in the laboratory from six common marine filter-feeders were measured. Species studied were the quarter deck (Crepidula fornicata), the tunicate (Molgula manhattensis), the hooked mussel (Brachidontes recurvus), the hard clam (Mercenaria mercenaria), the barnacle (Balanus eburneus), and the oyster (Crassostrea virginica). Length of individual pellets was measured to the nearest 0.1 millimeter under a microscope and their shape noted (Table 1). Pellets were introduced just below the surface of the water column in a soil analysis cylinder containing water with a salinity of $15^{\circ} \%$ at a temperature of $20^{\circ} \mathrm{C}$. The time required for each pellet to sink 10 centimeters was recorded to the nearest 0.25 second and sinking rate expressed in centimeters per second. The data were grouped into selected pellet-size intervals and are presented graphically in terms of the point and 95 percent interval estimate of the mean, $\bar{x} \pm s_{\bar{x}} t_{0.05}$, where $\bar{x}=$ mean, $S_{\bar{x}}=$ sample standard error, and $t_{0.05}=$ the 5 percent level of "student's" $t$ distribution (Snedecor, 1956).

The settling velocity of pellets collected on the 44-micron screen was 0.013 centimeter per second. Settling velocity of pellets collected in the laboratory varied with size and with the species producing them (Fig. 5). The smallest investigated were the ovoid pellets of $C$. fornicata, ranging in mean length from 0.25 to 0.75 millimeters. Sinking rates increased linearly from 0.42 to 0.88 centimeter per second. Next in size were the irregular rods of $M$. manhattensis, ranging in mean length from 0.52 to 1.45 millimeters. Sinking rates of this

TABLE 1. CHARACTERISTICS OF FECAL PELLETS COLLECTED IN THE LABORATORY AND USED FOR SINKING RATE DETERMINATIONS

\begin{tabular}{lccl}
\hline \multicolumn{1}{c}{ Species } & $\begin{array}{c}\text { No. pellets } \\
\text { measured }\end{array}$ & $\begin{array}{c}\text { Size range } \\
\mathrm{mm}\end{array}$ & \multicolumn{1}{c}{ Shape } \\
\hline B. recurvus & 135 & $0.6-3.0$ & thin ribbon; cross section crescentic \\
M. manhattensis & 83 & $0.6-1.4$ & irregular, hollow rod \\
C. fornicata & 64 & $0.3-0.5$ & pellets ovoid; cross section circular \\
M. mercenaria & 151 & $1.4-4.2$ & straight rod; cross section circular \\
B. eburneus & 109 & $1.0-3.4$ & $\begin{array}{l}\text { curved rod; cross section circular } \\
\text { C. virginica }\end{array}$ \\
& 86 & $1.0-3.8$ & $\begin{array}{c}\text { thin ribbon; cross section } \\
\text { bi-crescentic }\end{array}$ \\
\hline
\end{tabular}




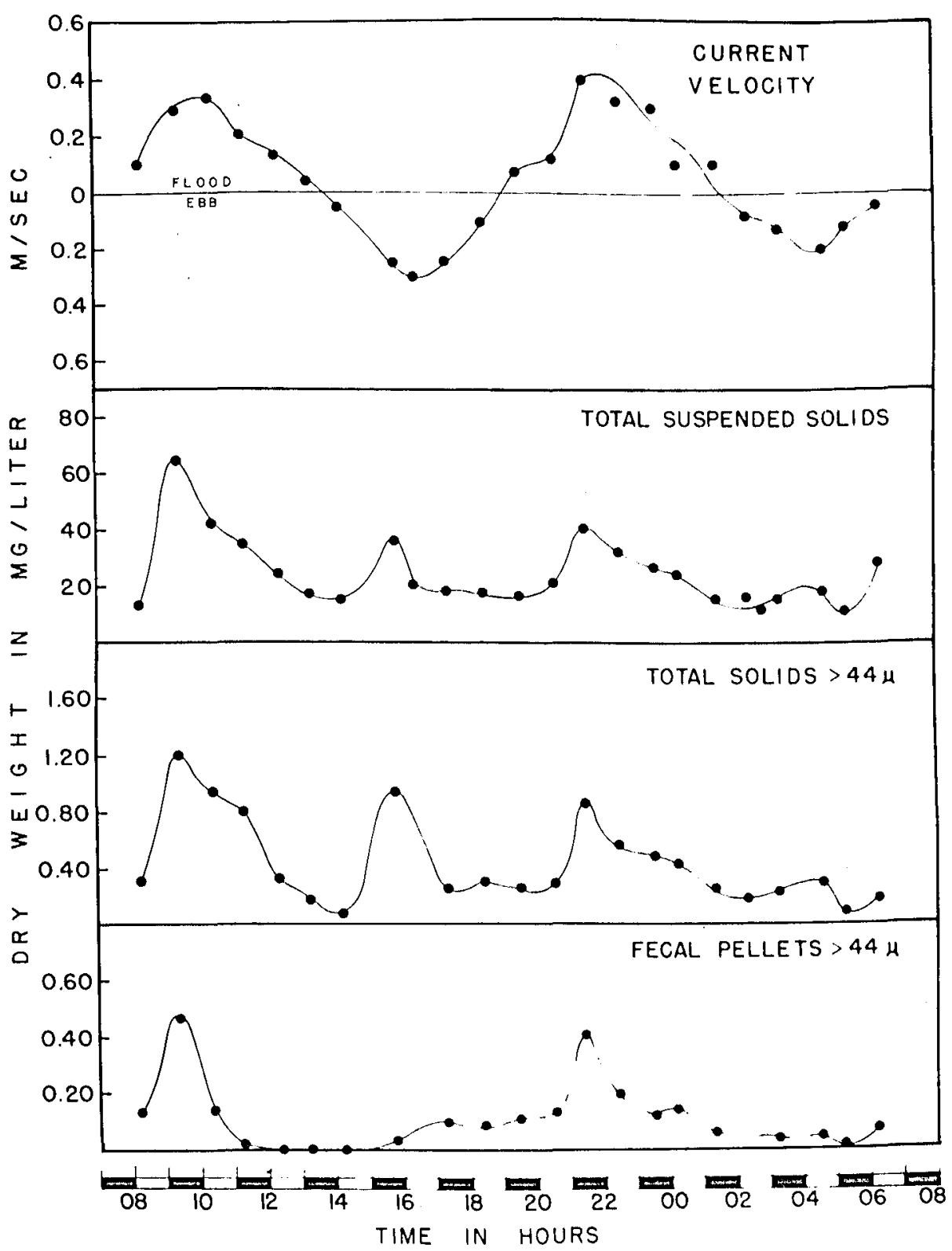

Figure 4. Relation between various components of the suspended sediment load and current velocity at a depth of $1 \mathrm{~m}$ above the bottom, White shoal, James River, 19-20 March 1965 (from Haven and Morales-Alamo, 1968).

species' pellets increased regularly from 0.80 to 1.40 centimeters per second.

Four of the invertebrates produced pellets in the 1- to 3.5-millimeters size range. Over this range, $B$. eburneus with round, rod-shaped pellets had the most rapid sinking rates. They increased in a linear manner from 1.04 to 1.72 centimeters per second. At comparable length intervals, the bi-crescentic ribbon 


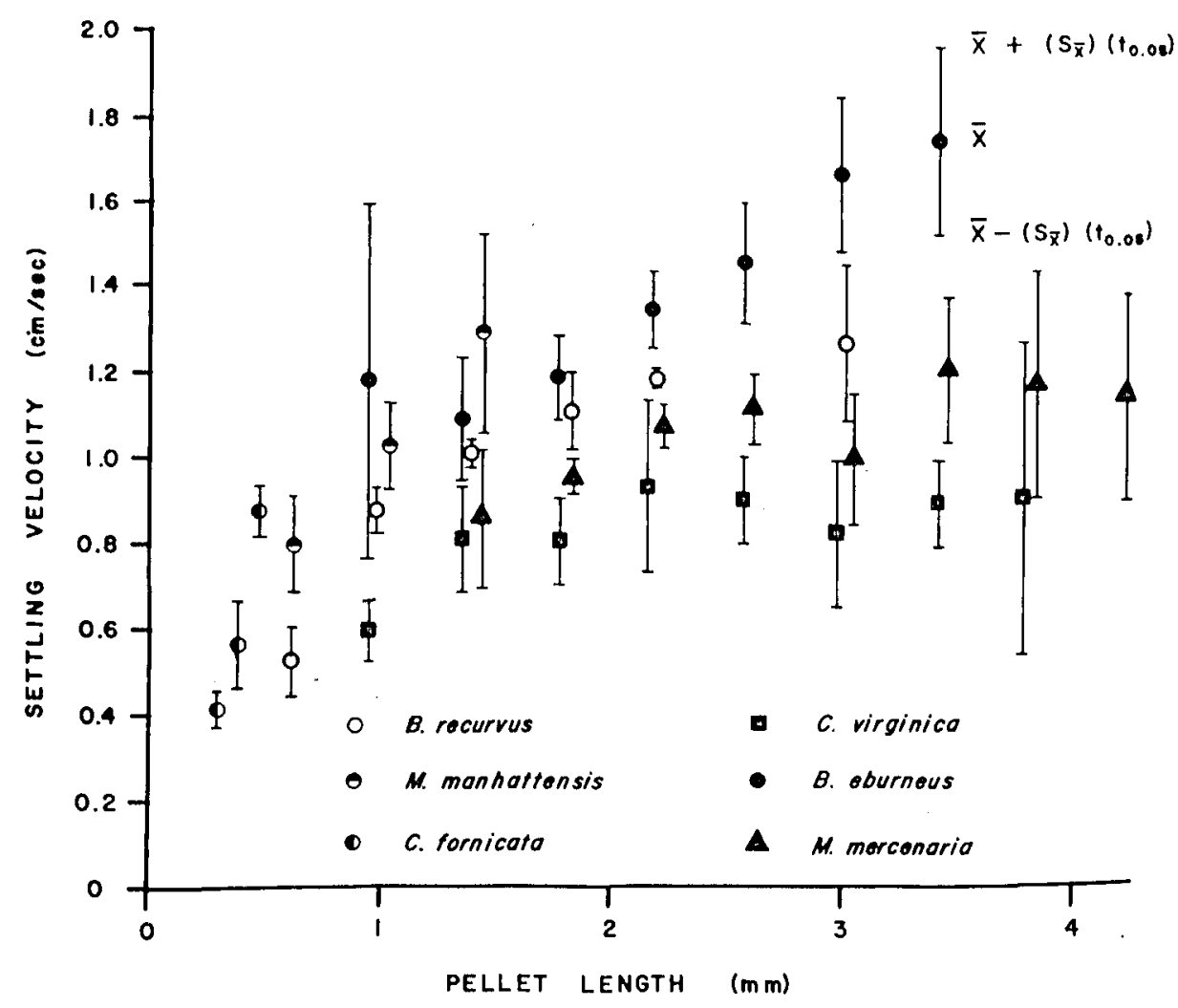

Figure 5. Settling velocity of fecal pellets from six species of invertebrate filter-feeders expressed as the mean and confidence interval around the mean for selected pellet-size intervals.

pellet of $C$. virginica settled more slowly. For this latter species, the rate increased from 0.58 centimeter per second for a length of 1.0 millimeter to about 0.75 centimeter per second for a length of 1.7 millimeters. Above this length, sinking rates appeared to remain constant. Sinking rates of the hollow, rod shaped $M$. mercenaria pellets and the crescentic ribbon pellets of $B$. recurvus were intermediate between those for pellets of $B$. eburneus and oysters.

Size of the particles composing fecal pellets was also measured. Pellets were washed in water with a salinity of $15 \%$ which had been previously filtered through a 0.2 -micron filter. Washed pellets were transferred to 5 milliliters of filtered river water of the same salinity and shaken for 5 minutes to break them up into their component particles. Particle counts and measurements were made with a Coulter electronic particle counter (Kubitschek, 1960). Particle sizes are expressed as equivalent diameters in microns. Results are expressed as the percent of total particles by volume below certain sizes.

From 82 to 93 percent by volume of the particles in the fecal pellets of quarter decks, tunicates, oysters, and hooked mussels were smaller than 4 microns; over 95 percent by volume in the same group were smaller than 9 microns (Fig. 6).

It was calculated that 2 - and 3-micron particles with the density of quartz will 
take 18 days to settle 1 meter (Haven and Morales-Alamo, 1968). This is much slower than pelletized material. Hydrodynamic sorting of pellets during transport by currents would tend to accumulate pellets in areas where the fine 2- to 4-micron particles would not settle ordinarily. Mechanical and bacterial activity following settling may break the pellets up; the component particles may remain bound in the bottom sediments or may be resuspended, depending on environmental conditions at the time.

\section{MIXING OF BIODEPOSITS INTO BOTTOM SEDIMENTS}

Biodeposits on estuarine bottoms are mixed into subsurface sediments by benthic invertebrates (Haven and Morales-Alamo, 1966b; Haven, 1968). This was demonstrated by placing biodeposits labeled with fluorescent particles or with radioactive tracers on sediment surfaces. Mixing occurred to depths of 10 to 15 centimeters in periods of less than 3 weeks.

\section{CONCLUSIONS}

Biodeposition is an extremely complex, cyclic process and is important in understanding transport and deposition of suspended solids. Transport of solids

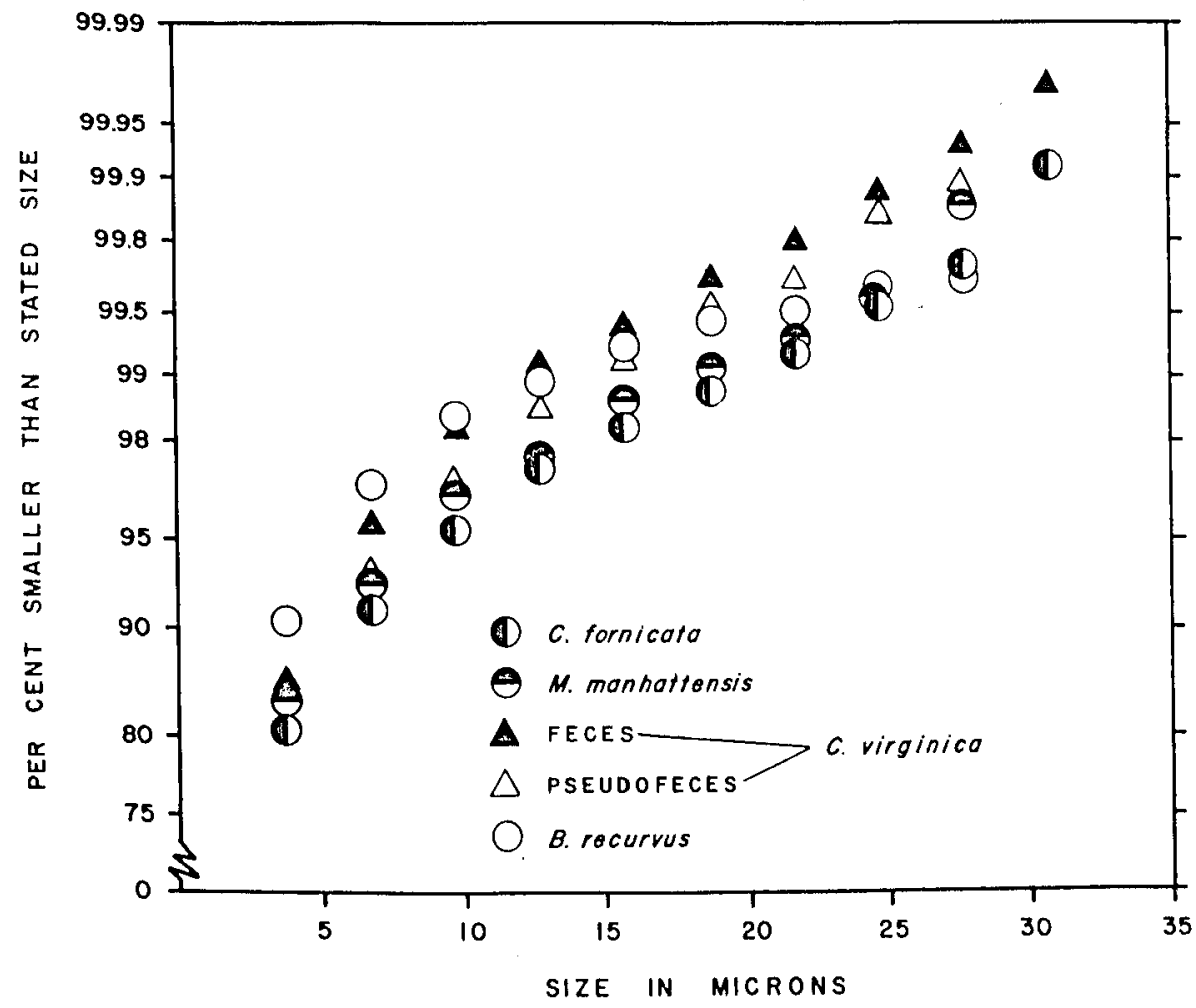

Figure 6. Size distribution of component particles of fecal pellets of four species of filter-feeders and of oyster feces and pseudofeces. 
through an estuary may not necessarily parallel that of the containing water mass, since transport of suspended sediments may be an intermittent process in which particulate matter exists alternately as fecal pellets in suspension, on the bottom, or in the bottom. When pellets are broken down by mechanical or bacterial action, this particulate matter may remain bound in the bottom or it may be resuspended. Quantities of pellet material that remain in the bottom may alter the textural and chemical composition of the bottom sediments, since their characteristics would be very different from the particles deposited by physical sedimentation. The existence and magnitude of this effect has not been studied.

\section{REFERENCES CITED}

Arakawa, K. Y., 1963, Studies on molluscan faeces (I): Pub. Seto Marine Biol. Lab., v. 11, p. 185-208.

Damas, D., 1935, Le role des organismes dans la formation des vases marines: Soc. Géol. Belgique Annales, v. 58, p. 143-152.

Haven, D. S., 1968, Concentration of suspended radioactive wastes into bottom deposits: U. S. Atomic Energy Commission, Final Report, Contract No. AT-(40-1)-2789.

Haven, D. S., and Morales-Alamo, R., 1965. Apparatus for holding individual oysters under equal water flows: Limnology and Oceanography, v. 10, p. 605-606.

- 1966a, Aspects of biodeposition by oysters and other invertebrate filter-feeders: Limnology and Oceanography, v. 11, p. 487-498.

- 1966b, Use of fluorescent particles to trace oyster biodeposits in marine sediments: Conseil Permanent Internat. Explor. Mer. Jour., v. 30, p. 267-269.

- 1968, Occurrence and transport of fecal pellets in suspension in a tidal estuary: Sed. Geology, v. 2, p. 141-151.

- 1970, Filtration of particles from suspension by the American oyster Crassostrea virginica: Biol. Bull., v. 139, p. 248-264.

Ito, S., and Imai, T., 1955, Ecology of oyster bed. I. On the decline of productivity due to repeated culture: Tohoku Jour. Agr. Research, v. 5, p. 251-268.

J $\phi$ rgensen, C. B., 1966, Biology of suspension feeding: New York, Pergamon Press, $357 \mathrm{p}$.

Kubitschek, H.E., 1960, Electronic measurement of particle size: Research, v. 13, p. 128-135.

Lund, E. J., 1957, A quantitative study of clearance of a turbid medium and feeding by the oyster: Inst. Marine Sci. Pub., v. 4, p. 296-312.

Moore, H.B., 1931, The specific identification of faecal pellets: Marine Biol. Assoc. United Kingdom Jour., v. 17, p. 359-365.

- 1936, The muds of the Clyde Sea area. III. Chemical and physical conditions; rate of sedimentation; and fauna: Marine Biol. Assoc. United Kingdom Jour., v. 17, p. 325-358.

Snedecor, G. W., 1956, Statistical methods: Ames, Iowa State College Press, 534 p.

Verwey, J., 1952, On the ecology of distribution of cockle and mussel in the Dutch Waddensea, their role in sedimentation and the source of their food supply, with a short review of the feeding behavior of bivalve molluses: Archives Néerlandaises de Zoologie, v. 10, p. 172-239.

MANUSCRIPT RECEIVED BY THE SOCIETY APRIL 12, 1971

CONTRIBUTION NO. 375 OF THE VIRGINIA INSTITUTE OF MARINE SCIENCE. SUPPORTED BY GRANT NO. AT-(40-1)-2789 FROM THE U. S. ATOMIC ENERGY COMMISSION 